\section{Insights on work in agriculture}

\author{
Benoît Dedieu $^{1} \cdot$ Sandra Schiavi ${ }^{2}$
}

Published online: 3 December 2019

(C) INRA and Springer-Verlag France SAS, part of Springer Nature 2019
Work in agriculture is a topic of major importance, considering the 1.3 billion of farmworkers $(25 \%$ of the world active population) and the ongoing climate, market, and digital changes, which raise many planet issues such as food security, biodiversity, greenhouse gas, and water. Employment is more and more one of these core issues, notably in southern countries, because of the migration fluxes, and employment in the rural areas. Agriculture means steering biological processes leading to food and more frequently non-food production. But it also means men and women, family workers, and wage earners engaged in farming. "Work in agriculture" is indeed a rather imprecise expression, covering various themes and discipline interests, but all dealing with (i) people at work (employment, gender, health, skills and know-how, job satisfaction...) and (ii) farming systems (labor, equipment, practices, off-farm activities, efficiency and resilience, indicators and values) (Darnhofer et al. 2012; Dedieu 2019) (Fig. 1).

This virtual issue gathers nine review and research articles published in Agronomy for Sustainable Development, providing novel insights on the diverse approaches of work in agriculture. Some of these articles were presented during the 1st International Symposium on Work in Agriculture in Maringa, Brazil, in 2016 (Dedieu and Damasceno 2016).

Malanski et al. (2019a) introduce this virtual issue by a bibliometric analysis of the Web of Science in order to explore what are the scientific communities and the thematic variations that refer to "work" or "labor." A general mapping of the communities is therefore possible, showing some connections but also disjunctions, between these communities. For

Benoît Dedieu

benoit.dedieu@inra.fr

Sandra Schiavi

smaschiavi@uem.br

1 INRA Sciences for Action and Development (SAD) Division, Saint Genès Champanelle, France

2 State University of Maringá (UEM), Maringá, Brazil example, approaches of work achieved by workers' health and ergonomics are rather apart from other social sciences. In this paper, research on work brings livestock farming systems framework as dominant in biotechnical-based discipline. Cournut et al. (2018) detail one of the most visible contributions of that community: the work assessment method. The framework of this method was inspired by approaches crossing ergonomics, economics, and livestock farming systems. The dissemination of the work assessment method in different countries for more than 15 years allows for a discussion on the relevance, limits, and various uses either to produce knowledge on work organization crossing routine and seasonal tasks and workers (decisional cell, others) or for extension purposes. The work of Delecourt et al. (2019) emerges from the crops farming/agronomy side. The purpose is less to provide a scientific interdisciplinary framework than to precise, via a participatory methodology, their needs for work-related information such as organization, working time, and skills in order to achieve more sustainable crop systems, notably when crop diversification is at stake. This information may be systemic (i.e., management of peak period) or targeted on one specific task duration. Two papers focus on the other major component of work: the labor force, and notably on the wage-earners. Malanski et al. (2019b) propose a framework aiming at analyzing changes in employees' work organization on mediumsize dairy farms since their recruitment, according to the tasks assigned, their level of specialization, and their autonomy. In such farms, workforce regularity is essential to perform laborintensive tasks, notably routine tasks such as milking and feeding that are important to structure the labor needs. Nettle et al. (2018) consider the workforce strategies (i.e., how farm work organization supports the needs and priorities of the farm) of Australian cotton farms. These strategies involve several workforce options (core, contract, casual) with several levels of skills and experience. There is a need for wage earners, but questions such as "what diversity?" or "what for and when?" must be addressed, taking into consideration the farm flexibility stakes, its financial capital, its infrastructures, and its human management practices. 

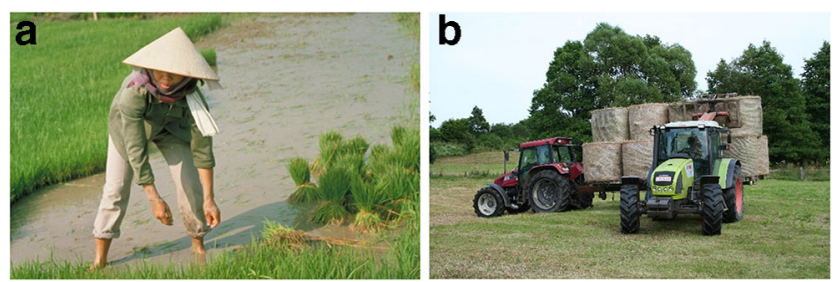

Fig. 1 a A farmer at work (Copyright J. Fourneau, INRA). b Farming machinery (Copyright S. Cournut, INRA)

Labor force, livestock, and crop management practices form a set of working activities (Leplat 1994) either manual, intellectual, or mediated by machines, automatons, and more and more by sensors. Machinery lightens the everyday burden of work and helps to be more precise when realizing tasks and to be more time-productive. Sensors provide information to make a decision. Baudron et al. (2019) focus their analysis on labor and mechanization in small-scale farms of sub-Saharan Africa, considering them as limiting factors for land productivity. They observe some interdependency between men and women's work intensity and assess the mechanization demand, mostly for pivot operations or for triggering technical operations during the cropping cycle.

Agriculture needs to evolve in response to global or local changes. How does work need to change? In what part, in response to technical improvement or as a condition for improvement? The High Level Panel of Experts' report "Sustainable agricultural development for food security and nutrition: what role for livestock" (HLPE 2016) proposed two guiding concepts. The first one is summarized as "sustainable intensification" (Petersen and Snapp 2015) since it considers both the yield increase and the decrease of agricultural negative impacts on the environment. The second one is "agroecologization" (Mendez et al. 2015) that advocates more natural resources and natural processes in farming, leading to less external inputs, more autonomous systems, and close connections to consumers. However, none of these two development concepts includes a clear precision on what must change in work. Referring to the concept of sustainable intensification, Dahlin and Rusinamhodzi (2019) propose a metaanalysis of the relation linking labor to yields, showing a deep variability in the interactions. They notably point out the fact that the use of low-cost herbicides is connected to high mechanization and reduced labor input. The reduction of herbicides appears here to be not only a biotechnical debate but also a work debate, notably in farms that build their competitivity with a high number of hectares per worker. Coquil et al. (2018) contribute to the agroecologization of agriculture. The assertion is that agroecologization is a change of farmers' work (actions, indicators, values) but the transformation of agriculture at a more significant level requires a change in the whole AKIS (Agriculture, Knowledge, and Information System) in order to integrate the singularity of each farmer's situation and the search for local solutions in the different professions' paradigms.

Is work in agriculture a new theme for advisory services? There is a need to take into account the new skills and professional know-how that are in debate for the development of sustainable agriculture. It is also necessary to consider the family, the men and women, the wage earners, their skills, their activities, and what makes job satisfying from their viewpoints. Dockès et al. (2019) summarize recent experiments developed in several countries, aiming at innovating what an "advice on work" could be at regional, collective, or individual levels. The first step is the understanding that work - and its various declinations - is a critical topic covering farms working conditions and job satisfaction indicators, and also the work efficiency as a condition for economic sustainability. The second is to accompany changes either in the workforce composition or in the farming system consistency and guidelines that are always backed with a specific work organization.

This virtual issue does not claim to cover all topics related to work in agriculture (Dedieu et al. 2019). Other topics could have been developed, such as the factors influencing farm employment dynamics, the importance of migrations, the delegation to contractors in the emergence of new models of farming — working systems, the persistence of MST health problems, and also the increasing signs of psychological distress in farmers. Beyond the portfolio of that diversity of questions, the ambition to connect the disciplinary themes to think together about the future of work must arise.

\section{References}

Baudron F, Misiko M, Getnet B, Nazare R, Sariah J, Kaumbutho P (2019) A farm-level assessment of labor and mechanization in Eastern and Southern Africa. Agron Sustain Dev 39:17-13. https://doi.org/10. 1007/s13593-019-0563-5

Coquil X, Cerf M, Auricoste C, Joannon A, Barcellini F, Cayre P, Chizallet M, Dedieu B, Hostiou N, Hellec F, Lusson JM, Olry P, Omon B, Prost L (2018) Questioning the work of farmers, advisors, teachers and researchers in agro-ecological transition. A review. Agron Sustain Dev 38:47-12. https://doi.org/10.1007/s13593-018-0524-4

Cournut S, Chauvat S, Correa P, Santos Filho JCD, Diéguez F, Hostiou N, Pham DK, Servière G, Sraïri MT, Turlot A, Dedieu B (2018) Analyzing work organization on livestock farm by the Work Assessment Method. Agron Sustain Dev 38:58-16. https://doi.org/10.1007/ s13593-018-0534-2

Dahlin AS, Rusinamhodzi L (2019) Yield and labor relations of sustainable intensification options for smallholder farmers in sub-Saharan Africa. A meta-analysis. Agron Sustain Dev 39:32-18. https://doi.org/10.1007/ s13593-019-0575-1

Darnhofer I, Gibbon D, Dedieu B (Eds) ( 2012) Farming systems research into the 21st century: the new dynamic.Dordrecht: Springer. https:// www.springer.com/fr/book/9789400745025

Dedieu B (2019) Transversal views on work in agriculture. Cah Agric 28:8. https://doi.org/10.1051/cagri/2019008

Dedieu B. Damasceno J.C. (2016) Complex realities and transformation in work in a diversity of farming models. International Symposium on Work in Agriculture - Maringa, Brazil - 2016. www.workinagriculture.com/ 
IAWA-Activities/International-Symposium-on-Work-inAgriculture-Maringa-Brazil-2016. Accessed 8-11 Nov 2016

Dedieu B, Damasceno JC, Neiman G, Schiavi S (Coordinators) (2019) Multifacet realities of work in agriculture. Cah Agric 28. https://www. 180 cahiersagricultures.fr/fr/component/toc/?task=topic\&id=883

Delecourt E, Joannon A, Meynard JM (2019) Work-related information needed by farmers for changing to sustainable cropping practices. Agron Sustain Dev 39:28-12. https://doi.org/10.1007/s13593-0190571-5

Dockès AC, Chauvat S, Correa P, Turlot A, Nettle R (2019) Advice and advisory roles about work on farms. A review. Agron Sustain Dev 39:214. https://doi.org/10.1007/s13593-018-0547-x

HLPE (2016) Sustainable agricultural development for food security and nutrition: what roles for livestock? A report by the High Level Panel of Experts on food security and nutrition of the Committee on World Food Security, Rome

Leplat J (1994) Collective activity in work: some ways of research. Le Travail Humain 57:209-226

Malanski PD, Schiavi S, Dedieu B (2019a) Characteristics of "work in agriculture" scientific communities. A bibliometric review. Agron Sustain Dev 39:36. https://doi.org/10.1007/s13593-019-0582-2
Malanski PD, Ingrand S, Hostiou N (2019b) A new framework to analyze changes in work organization for permanent employees on livestock farms. Agron Sustain Dev 39:12. https://doi.org/10.1007/s13593019-0557-3

Mendez VE, Bacon CM, Cohen R, Gliessman SR (2015) Agroecology: a transdisciplinary, participatory and action-oriented approach. Available at https://www.crcpress.com/Agroecology-A-Transdis ciplinaryParticipatory-and-Action-oriented-Approach/MendezBacon-Cohen-Gliessman/p/book/9781482241761. Accessed 2 December 2015

Nettle R, Kuehne G, Lee K et al (2018) A new framework to analyse workforce contribution to Australian cotton farm adaptability. Agron Sustain Dev 38:38. https://doi.org/10.1007/s13593-018-0514-6

Petersen B, Snapp S (2015) What is sustainable intensification? Views from experts. Land Use Policy 46:1-10. https://doi.org/10.1016/j. landusepol.2015.02.002

Publisher's note Springer Nature remains neutral with regard to jurisdictional claims in published maps and institutional affiliations. 